\title{
Local labor markets and taste-based discrimination
}

\author{
Clémence Berson ${ }^{1,2}$
}

\author{
Correspondence: \\ clemence.berson@banque-france.fr \\ ${ }^{1}$ Banque de France, 31, rue Croix \\ des petits champs, 75001 Paris, \\ Erance \\ ${ }^{2}$ CES-University Paris 1, Paris, France
}

\begin{abstract}
This article appeals to heterogeneity in workers' non-wage preferences to model taste-based discrimination. Firms hire both types of workers and pay lower wages to minority workers, whatever their taste for discrimination. A single prejudiced firm in the market produces a substantial wage gap in all firms. Consequently, discrimination allows unprejudiced firms to make non-zero profits, so that they have little incentive to drive out prejudiced firms. As the market does not eliminate discrimination, state intervention is required. Indirect policies do not affect the absolute wage gap between the two groups, but may be more likely to be used than direct policies.
\end{abstract}

Keywords: Discrimination, Oligopsony, Wage gap

JEL Classification: J42, J71, L13

\section{Introduction}

Competition and discrimination on the labor market are closely related both in theory and in empirical work. The main finding, which comes from the Becker (1971)'s model, is that competition has a negative impact on discriminatory outcomes. The concept of discrimination was introduced into economics by Becker as the differential treatment of two individuals with identical observable productive characteristics, due to an observable non-productive characteristic. Becker suggests that discrimination reflects the taste of employers, coworkers, or customers. In this framework, members of the group which is discriminated against receive lower wages in order to be hired and accepted as employees, coworkers,or salespersons. This analysis was criticized by Arrow (1971), who argued that the model is unstable and that discrimination will disappear via competition. Perfect competition produces a zero-profit market, so that prejudiced firms, which are less competitive due to their higher wages, exit the market. Their continued presence requires them to make extra profit or be more productive than other firms in order to stay in the market. By way of reaction, Phelps (1972) and Arrow (1971) improved the explanation of discrimination by considering it as a result of beliefs. When workers do not belong to their own group, employers use an expectation, real or assumed, of the productivity levels of groups of workers as a whole to set the offered wage. In general, firms believe that workers in other groups are less productive on average than those who are in the majority. Minority group workers thus earn less than their majority counterparts. This statistical discrimination will disappear over time as 
employers learn the true productivity of their workers, except if firms can use their market power against the discriminated workers. Altonji and Pierret (2001) highlight this phenomenon using job characteristics and workers' results to AFQT tests in the USA.

Empirical work provides support for Becker's theory by showing that greater competition reduces wage differentials, although discrimination persists. These results depend on two key inputs: the measures of competition and labor market discrimination. First, exogenous competitive shocks to a particular sector show that competition reduces the wage gap by gender and by race, enabling workers in the discriminated group to attain higher job positions. ${ }^{1}$ Second, the comparison of different sectors with different degrees of competition within a country shows that the wage gap is lower in less concentrated markets. ${ }^{2}$ Third, the international trade liberalization reduces the gender wage gap. ${ }^{3}$ The main conclusion from these papers is that imperfect competition justifies the persistence of discrimination on the labor market. This implies that prejudiced companies receive rents or are more productive than other firms and can thus satisfy their taste for discrimination while remaining competitive and staying in the market.

The above analysis focuses on the relationship between product market competition and discrimination. However, discrimination is not only inconsistent with competition on the product market but it also provides a challenge to the existence of labor market competition. In the latter, workers are paid according to their marginal productivity, and two workers with identical ability should receive equal pay. Nevertheless, with discrimination, employers do not pay workers at marginal productivity and take non-productive worker characteristics into account. In order to be wage setters, employers need some market power in order to fix the wage. Consequently, imperfection on the labor market is one argument for the persistence of discrimination in a competitive product market and, as this paper shows, will lead every firm to discriminate, whatever their tastes or beliefs.

Theoretical search models of discrimination use to explain discrimination persistence using labor market frictions. ${ }^{4}$ In particular, Black (1995) explains the lower wage of minority workers by their lower reservation wage due to a smaller number of job offers. The model developed below confirms previous findings of matching models as the persistence of discrimination, induced by imperfection of the labor market. However, it releases some assumptions and uses new channels to explain the wage gap. The results highlight the importance of firms' location in the wage gap. Moreover, as discrimination is persistent, the paper studies several public policies aiming at fighting discrimination.

In this paper, discrimination is introduced in a taste-based model where workers are not paid at marginal productivity. Workers' utility functions include the non-wage characteristics of the job. Heterogeneity in worker preferences allows firms to exercise market power in the labor market, which is thus oligopsonistic. According to the theoretical arguments in Manning (2003a) and as shown by an increasing literature, considering the labor market as oligopsonistic reflects reality. Boal and Ransom (1997) and more recently Manning (2011) summarize studies highlighting monopsony and point out issues at stake. Empirically, Staiger et al. (2010) and Ransom and Sims (2010) show monopsony with respect to nurses and teachers in the USA, respectively. Booth and Katic (2011) estimate labor supply 
elasticity around 0.7 in Australia, confirming monopsony power existence. Falch (2011) points out monopsony in Norway concerning teachers. Barth and DaleOlsen (2009) indicate that 70-90\% of the gender wage gap among low-skilled workers is explained by monopsonistic discrimination. Ransom and Oaxaca (2010) estimate labor elasticities between 1.5 and 2.7 in US grocery stores depending on sex.

This model of oligopsony with heterogeneous worker preferences is based on Salop (1979), who enriches the Hotelling (1929)'s model with a circle city. This model of oligopsony with heterogeneous worker preferences is based on a combination of both concepts. In the presence of taste-based discrimination, it yields an enduring wage gap between the majority and the minority without worker segregation. Consequently, this model does not exactly reproduce geographical breakdown by ethnicity and fits better gender than race discrimination. The main contributions of this paper are, first, that discrimination does not come from a productivity gap, real or assumed, between minority and majority group workers. Second, a single prejudiced firm is sufficient to induce a significant wage gap in the market. Further, non-prejudiced firms discriminate against the minority without having any taste for discrimination or beliefs regarding them. Furthermore, firms make more profits when they are located in an area close to similar firms. If higher competition decreases the wage gap, it totally vanishes if and only if commuting costs disappear or if the number of firms tends to infinity. Moreover, unprejudiced firms have no incentive to compete with prejudiced firms to drive the latter out, as they profit from the existence of discrimination. Consequently, discrimination can persist even in the long term. As discrimination will not disappear via competition, governments consequently have to introduce public policies. In this paper, these consist of equal wage laws, employment subsidies, introduction of a minimum wage, affirmative action, and transport improvements and subsidies.

To my knowledge, this is the first time that this model has been applied to the issue of labor market discrimination. Thisse and Zenou (1995), Wauthy and Zenou (1999), and Hamilton et al. (2000) have used this model to analyze employment and training policies. Bhaskar and To (2003) have also employed it to consider wage dispersion and survey the possible uses of the model in Bhaskar et al. (2002).

This paper is organized as follows. The model is described in Section 2 for the case of four firms, with an analysis of the effects of competition on wages. Section 3 then sets out the policy implications. Finally, Section 4 concludes.

\section{The model}

\subsection{General framework}

The labor market is assumed to be oligopsonistic to take employer market power into account. The market is made up of $n_{F}$ firms uniformly distributed around a circle city. The distance between any two firms is $\frac{1}{n_{F}}$. To simplify the resolution of the model, there is no free entry or exit in the market. The cost of entry in the market is $F$, which could be considered as the minimum level of capital required to produce. Each firm uses only labor as an input in order to produce a good sold at price $p$ on a competitive market. Each worker produces one unit of output during the period. 
The labor market is composed of a continuum of workers split into two types: Greens and Reds. The two worker types differ only in an observable characteristic which is uncorrelated with their productivity. The Reds represent a proportion $\gamma$ of the working population, and both types of workers are identically distributed around the circular market. The length of the circle city correspond to the number $n_{W}$ of workers in the city. Consequently, the market is composed of $n_{W}^{R}=\gamma n_{W}$ Red workers and $n_{W}^{G}=(1-\gamma) n_{W}$ Greens. The cost of moving is supposed to be too high to be compensated by higher wages. Workers who are discriminated against cannot then move closer to unprejudiced firms. This is consistent with low mobility of workers, underline by Wasmer (2006), Rupert and Wasmer (2007) and Lemoine and Wasmer (2010), and the theory of thin labor markets developed and summarized in Manning (2003a). Moreover, Manning and Petrongolo (2011) show that the utility of being offered a job sharply decays with distance to the job in the UK. This confirms previous findings of Bonhomme and Jolivet (2009) for Europe. There are two types of employers: the first has discriminatory tastes and the second is indifferent over the observable characteristic distinguishing workers. A proportion $\eta$ of employers, noted $n_{F}^{p}=\eta n_{F}$, are taste-based prejudiced against the minority workers. Let $d$ be the monetary term denoting the manager's psychic cost of hiring a Red worker. In this model, the labor market is assumed to be covered. However, if commutation costs or discrimination are too high, unemployment becomes a possible state. Appendix 2 deals with this issue.

\subsection{Labor supply}

In order to work, Reds and Greens have to go to a firm $i$. All travel occurs along the circle and a worker who covers a distance $x_{i}$ to work in the firm $i$ spends $t x_{i}$, where $t$ is the commutating cost (see Fig. 1). The introduction of distance to job is equivalent to introducing heterogeneity in worker preferences. This is a physical distance but it can also be interpreted as a non-wage job characteristic offered by the firms (type of contract, full or part-time, etc.), firm characteristics themselves (size, environmental, or social policies, etc.), or informational frictions. This implies that different jobs are not perfect substitutes for each other. Consequently, labor supply does not react to small movements in wages: the wage elasticity of labor supply is small. This heterogeneity leads to market power in the firms' favor, which latter can set wages and enjoy an oligopsony position in the labor market. This is consistent with Manning and Petrongolo (2011), who show that a large number of local labor markets compose British labor market because of a relatively high cost of distance. Brueckner et al. (2002) point out the importance of urban location in the presence of monopsony and how wages are affected by this market power.

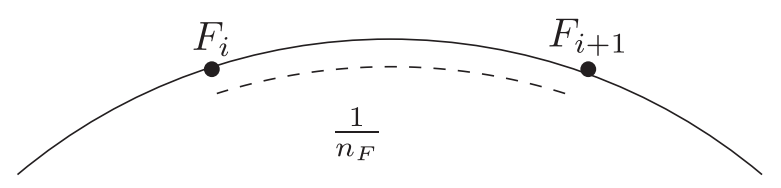

Fig. 1 Dispersion of firms 
Let $w_{h i}$ denote the wage offered by firm $i$ to workers in group $h$. A worker will accept a job offer only if her net wage is higher than the reservation wage. To keep the framework simple without loss of generality, the reservation wage is normalized to zero. The worker's net wage is the wage offered by the firm minus the commuting cost. As a worker of group $h$ working at $x_{i}$ pays a commuting cost $t x_{i}$, her net wage is $w_{h i}-t x_{i}$. In other words, she or he is willing to work for firm $i$ if the transportation costs are lower than the offered wage. However, firm $i$ is not alone on the market and workers compare the net wages offered by every firm and will work for firm $i$ only if the net wage there is the highest. Formally, she or he will work for firm $i$ only if $w_{h i}-t x_{i}>w_{h k}-t\left(\frac{1}{n_{F}}-x_{i}\right)$ for all $k$.

When we have $\left|w_{h i}-w_{h i+1}\right| \leq \frac{t}{n_{F}}$ for each $i$ and $t$ sufficiently small, i.e., a moderate discrimination to obtain wage dispersion, workers located between $i$ and $i+1$ have no incentive to work for any firm other than $i$ or $i+1$. The case of a small transportation cost is studied in Appendix 3. They decide according to the net wage offered by each firm. Both types of workers are uniformly distributed around the circle, so that decision-making is identical whatever group the worker belongs to. This means that they compare the wage set by firm $i$ minus the transport cost to work at $i$ to that offered by firm $i+1$ minus the commuting cost of working at $i+1$. With the previous notation, an individual chooses firm $i$ if $w_{h i}-x_{i} t>w_{h i+1}-\left(\frac{1}{h_{F}}-x_{i}\right) t$. The worker of type $h$ located at $\tilde{x}=\frac{1}{2 t}\left(\frac{t}{n_{F}}+w_{h i}-w_{h i+1}\right)$ is indifferent between working for firms $i$ and $i+1$. All workers located below her will work for firm $i$ as their transport costs are lower; the others will work for firm $i+1$. Since there is a similar set of workers on the other side of firm $i$, their labor supply is symmetric. Consequently, the labor supply to firm $i$ is

$$
L_{i}^{j}\left(w_{R i}^{j}, w_{G i}^{j}\right)=\gamma \frac{1}{t}\left(\frac{t}{n_{F}}+w_{R i}^{j}-\bar{w}_{R i}\right)+(1-\gamma) \frac{1}{t}\left(\frac{t}{n_{F}}+w_{G i}^{j}-\bar{w}_{G i}\right)
$$

where $\bar{w}_{h i}=\frac{1}{2}\left(w_{h i-1}+w_{h i+1}\right)$ is the average of the wages offered by the direct neighbors of firm $i$. As firms face both types of workers, the labor supply is composed of both Greens and Reds (the right and left hand sides, respectively). In accordance with Robinson (1934), if labor supply elasticities vary across groups, the firm can set wages separately for each groups even if workers are equally productive.

\subsection{Labor demand}

The employer's utility function contains both profits and a parameter reflecting the disutility associated with the employment of Red workers. This means that only Red workers face discrimination, due to the observable characteristics that, without affecting their productivity, differentiate them from other workers. The owner of a representative discriminatory firm $i$ is assumed to maximize utility over the objectives of profit, the employment of Green workers, and the employment of Red workers, denoted by $U_{i}^{j}\left(\Pi_{i}^{j}, L_{G i}^{j}, L_{R i}^{j}\right)$ where $\Pi_{i}^{j}$ is the firm $i$ 's profit. Employers will hire workers as long as the marginal utility of doing so is positive. To attract more 
workers, firms have to offer higher wages to compensate for greater commuting costs. The utility function of both discriminatory and non-discriminatory firms is generically

$$
U_{i}^{j}\left(\Pi_{i}^{j}, L_{G i}^{j}, L_{R i}^{j}\right)=p\left(L_{G i}^{j}+L_{R i}^{j}\right)-w_{G i}^{j} L_{G i}^{j}-\left(w_{R i}^{j}+d_{i}\right) L_{R i}^{j}-F
$$

where $d_{i}=d$ if firm $i$ is prejudiced and 0 otherwise. $L_{h i}^{j}$ is the number of employees of group $h$ at the firm. The utility of employers is closely related to their profits: $U_{i}^{j}\left(\Pi_{i}^{j}, L_{G i}^{j}, L_{R i}^{j}\right)=\Pi_{i}^{j}-d_{i} L_{R i}^{j}$. Without taste-based discrimination, utility and profit are equal. The prejudiced firms have a lower utility because of the taste for discrimination against Reds.

In this model, firms compete via wages to attract workers. They thus take into account the behavior of their neighbors and introduce the wage offered by neighboring firms in their optimization program to determine their own wage. The maximization of utility produces their reaction function(s). Substituting the labor supply Eq. (1) into the utility function (2) and then solving the first-order condition yields firms' optimal wages as

$$
\begin{array}{r}
w_{G i}=\frac{1}{2}\left(p-\frac{t}{n_{F}}+\bar{w}_{G i}\right) \\
w_{R i}=\frac{1}{2}\left(p-\frac{t}{n_{F}}+\bar{w}_{R i}-d_{i}\right)
\end{array}
$$

As every firm takes its neighbors' decisions into account, firm $i$ is affected by the decisions of all other firms. Moreover, it is worth noting that the discrimination term does not appear directly in the reaction function of unprejudiced firms: their reaction function is the same for Greens and Reds, and the wage gap comes from the term reflecting neighboring wages. As established by Robinson (1934), nondiscriminatory firms then take advantage of the reduced demand for Red workers to offer them lower wages. The presence of one prejudiced firm in the market affects the wages of all Reds, even if their employer is not prejudiced. Consequently, a wage gap between Reds and Greens pertains in every firm in the market. It is important to note that higher competition induces lower commutation cost and higher wages. However, discrimination vanishes only if workers can freely choose their employer's location, i.e., when the number of firms tends to infinity. More details are given in Subsection 2.5.

\subsection{Equilibrium}

Following Bhaskar and To (2003), a unique Nash equilibrium solves this game in wages even in the presence of discrimination. The proof is described in Appendix 1. The wages of Greens are not affected by the taste for discrimination. They are identical for all firms, as the reaction functions are the same across firms, with $w_{G i}=p-\frac{t}{n_{F}}$. This wage does not equal worker productivity due to the commuting costs. Wage dispersion will result when firm productivity is heterogeneous. However, I here retain a simple framework in order to bring out 
the results better. I thus assume uniform productivity without loss of generality. The wages of Reds depend on the proportion of prejudiced firms on the market and their dispersion on the circle. If $\eta=1 / 2$ and prejudiced firms are uniformly distributed, i.e., the different firm types alternate, the wages of Reds are

$$
\begin{aligned}
& w_{R i}^{u}=p-\frac{t}{n_{F}}-\frac{1}{3} d \\
& w_{R i}^{p}=p-\frac{t}{n_{F}}-\frac{2}{3} d
\end{aligned}
$$

If $\eta=1 / 3$ and prejudiced firms are uniformly distributed, i.e., a prejudiced firm is circled on two sides by unprejudiced firms but an unprejudiced firm is surrounded by a prejudiced and an unprejudiced firms, the wages of Reds are

$$
\begin{aligned}
& w_{R i}^{u}=p-\frac{t}{n_{F}}-\frac{1}{5} d \\
& w_{R i}^{p}=p-\frac{t}{n_{F}}-\frac{3}{5} d
\end{aligned}
$$

The mean wage gap with one half of prejudiced firm on the market is $\frac{1}{3} d$, declining to $\frac{2}{5} d$ with one third of discriminatory firms. The proportion of prejudiced firms on the market positively affects the mean wage gap between Reds and Greens. Indeed, the less prejudiced firms there are, the lower is their influence on other wages.

To explore the impact of firm dispersion on the circle, suppose that $\eta=1 / 2$ and $n_{F}=4$ and compare when the different firm types alternate and when two similar firms are adjacent (two $u$ type firms are followed with two $p$ type firms, followed by two $u$ firms and so on) (Table 1). The equilibrium wage of Greens is not sensitive to firm dispersion, but the wage of Reds is. When prejudiced and unprejudiced firms alternate (case A), equilibrium wages for Reds are

$$
\begin{aligned}
& w_{R i}^{u}=p-\frac{t}{n_{F}}-\frac{1}{3} d \\
& w_{R i}^{p}=p-\frac{t}{n_{F}}-\frac{2}{3} d
\end{aligned}
$$

and when two identical firms are adjacent (case B), equilibrium wages are

$$
\begin{aligned}
& w_{R i}^{u}=p-\frac{t}{n_{F}}-\frac{1}{4} d \\
& w_{R i}^{p}=p-\frac{t}{n_{F}}-\frac{3}{4} d
\end{aligned}
$$

The wage gap between Reds and Greens is less than $d$ in prejudiced firms due to competition with unprejudiced firms. It is worth noting that the Red wage offered by non-discriminatory firms is lower than that of Greens. This explains why unprejudiced firms are less tempted to expel prejudiced firms as the latter are the source of their profit. In both cases, the mean wage of Reds is $p-\frac{t}{n_{F}}-\frac{1}{2} d$. Consequently, the mean wage gap is not affected by firm dispersion. However, the wage 
differential between the Reds employed by prejudiced and unprejudiced firms is larger when identical firms are side by side than when they alternate. In case $A$, a Red worker employed by an unprejudiced firm earns $\frac{1}{3} d$ more than one employed by a prejudiced firm, as against only $\frac{1}{4} d$ in $B$. The dispersion of firms (Fig. 1) around the circle affects the standard deviation of the wages of workers who are discriminated against but does not affect the mean wage of Red workers. Impacts of discrimination could be reduced by two ways: government can reduce inequalities and decrease standard deviation of the wage gap or decreasing the mean wage gap.

The payroll depends on the intensity of discriminatory taste, firm dispersion, and the number of firms on the market-see Appendix 4 for calculations. As shown in Manning (2010) and in accordance with data, wages and firm size are positively correlated. The wage bill of Greens is identical whatever the firm and equals $(1-\gamma) \frac{1}{n_{F}}$. All of the variation in the payroll comes from the Reds. The wage bill is lower in prejudiced firms. But it increases with the closeness of other prejudiced firms. When two prejudiced firms are side-by-side, their power over the Reds located between them is greater and they can offer a lower wage and attract more Reds than when their neighbor is an unprejudiced firm, which offers a higher wage.

Moreover, the wage bill affects profits: as productivity is constant, firms' profits will rise with employment as long as the wage set is less than marginal productivity. In order to attract an additional worker, the employer has to increase slightly the wage to compensate for commuting costs of more distant individuals. The higher is the wage bill, the higher are wages, as the labor supply curve is not perfectly elastic. Profits are sensitive to discrimination and firm dispersion. In both cases, discrimination increases the profits of all firms, but more so in unprejudiced than in prejudiced firms. Moreover, profits are higher for unprejudiced firms and when these alternate with prejudiced firms. They increase with the taste for discrimination. Prejudiced firms make less profit but these increase with the proximity of similar firms.

To summarize the results here, the presence of one prejudiced firm on the market induces a lower wage for all of the workers who are discriminated against, as in the model of Black (1995). In addition, unprejudiced firms also make additional profit and have little incentive to compete against each other to drive out prejudiced firms. If they did, prejudiced firms would be replaced by nondiscriminatory firms, reducing the profits of established firms. Last but not least, firms make more profit when they are located in an area close to similar firms.

\subsection{The impact of competition}

Becker assumes that competition affects the extent of discrimination on the labor market. The more competition there is, the less the taste for discrimination can be satisfied. We here analyze how a new firm on the market impacts discrimination and show that the presence of imperfection on the labor market reduces the impact of competition in the product market on discrimination. Two different types of entry are modelized. 
An increase in the number of firms $n$, due to lower entry costs $F$ or better technology, has a positive effect on labor market competition. The more firms there are on the market, the closer we are to perfect competition. If we consider this change at the beginning of the game, this model is static and firms are uniformly distributed around the circle. As the number of firms increases, and if they remain uniformly distributed, then the distance between firms is reduced and the impact of transportation costs on wages is lower. Wages thus rise with the number of firms and become closer to worker productivity as commuting costs become smaller. Even so, the impact of discrimination remains the same as that described above. The presence of some commuting costs prevents the total disappearance of discrimination.

Nevertheless, the effect is different if the dispersion of existing firms is invariant. If existing firms are already located on the circle, and the new one is inserted between two old firms, then firms are no longer uniformly distributed around the circle and the distribution of market power changes. The market power of firms in the neighborhood of the new entrant falls, whereas that of firms further away rises. The former consequently fix a lower wage than do the others. Indeed, firms do not differentiate workers located on the right side from workers of the other side. As the market is asymmetrical, firms further away could take over workers of their neighbors, which set a lower wage to compete against the new firm.

In both cases: a new unprejudiced firm reduces the impact of discriminatory tastes whereas a new prejudiced firm increases it.

In this paragraph, I consider the case where $n=4$ to explore more easily the properties of the model. Assume that a fifth firm wants to enter the market. It locates itself between two existing firms (see Fig. 2). Depending on the dispersion of the other firms, it can be located between two identical firms or two different firms. In both cases, the distance between the new firm and its neighbors is $1 / 8$ instead of $1 / 4$ in the rest of the circle. Consequently, the sharing of market power changes: the market power of the existing firms $F_{1}$ and $F_{2}$, near the new entrant, falls because of the closeness of this new firm. On the contrary, both firms $F_{3}$ and $F_{4}$, which are not neighbors to the new firm, have greater market power and can set lower wages for their workers and attract more workers. Indeed, there is less competition on this side of the circle. Consequently, their payroll increases because $F_{1}$ and $F_{2}$ set a lower wage than before to compete against the new firm.

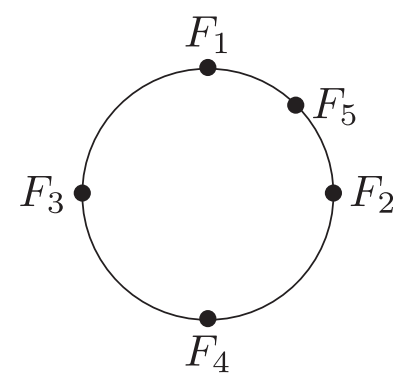

Fig. 2 A fifth firm enters the market 
Moreover the new firm, whether prejudiced or not, will choose to set up in the neighborhood of prejudiced firms in order to pay Red workers less. The introduction of a prejudiced new firm will also lower the wages of Reds in other firms. An unprejudiced firm with prejudiced neighbors employs more Red workers than its neighbors; it also earns more profits than its neighbors (as it hires more Red workers) and earns more profits than if it had located in an area with non-prejudiced neighbors. The new firm thus benefits from the presence of prejudiced firms in its immediate neighborhood.

New firm entry therefore affects the sharing of market power. Strategically, the new entrant will locate where the greatest number of prejudiced firms are found but does not systematically decrease discrimination.

\section{Policy implications}

The analysis above has shown that greater competition reduces the wage gap but does not eliminate it. Since imperfect competition is clearly the reality (Manning (2003b)), governments have to implement suitable policies in order to decrease the wage gap due to discrimination. This section describes a number of possible policies, direct or indirect, aiming to fight discrimination. The government here wants to reduce the wage differential between Green and Red workers and maximize the welfare. It finances these policies by public loan or a flat rate $\operatorname{tax}$ noted $\beta$. Without any government intervention, the global welfare is

$$
W=p-\frac{1}{16} t-\gamma d+\gamma \frac{5}{9} \frac{d^{2}}{t}
$$

This welfare increases when competition on the labor market is higher ( $t$ lower or $n_{F}$ higher). The impact of discrimination is more ambiguous: when $d$ is higher, the surplus of firms increases but the welfare of workers decreases, depending on the number of Reds. Derivatives are in Appendix 5. In order to better examine the impact of policies, $n_{F}=4$ with half of the firms, which are prejudiced. Prejudiced and unprejudiced firms alternate on the circle city.

\subsection{Employment subsidies}

The government can decide to subsidize the wages of Reds in order to compensate for discrimination. This policy is not currently used in order to decrease gender gap. However, it exists concerning young people and low-skilled workers in France for instance, the most remote from employment in Canada or disabled in several countries.

The subsidy is allocated to every firm based on the stock of Red workers on its books to pull up the wage rates of all discriminated workers. As the government does not know the type of firms, it subsidizes the wages of all Reds and not only those hired by prejudiced firms. The utility function of firms becomes $U_{i}^{j}=p L_{i}^{j}-\beta L_{i}^{j}-w_{G i}^{j} L_{G i}^{j}-$ 
$\left(w_{R i}^{j}+d_{i}-s\right) L_{R i}$, where $s$ is the subsidy per Red worker. Maximization leads to following reaction functions:

$$
\begin{aligned}
w_{G i}^{j} & =\frac{1}{2}\left(p-\beta-\frac{t}{4}+\bar{w}_{G i}\right) \\
w_{R i}^{j} & =\frac{1}{2}\left(p-\beta-\frac{t}{4}+\bar{w}_{R i}-d_{i}+s\right)
\end{aligned}
$$

The global welfare is $W=p-\beta-\frac{1}{8} t+\gamma s-\gamma \frac{5}{3} \frac{d^{2}}{t}$. If the government is budget constrained, receipts and expenses are set equal to each other and $\beta=$ $s \frac{L_{R}}{L}=\gamma s$. If the government finances by borrowing, it does not need taxes and $\beta=0$. In both cases, the subsidy on the wages of Red workers raises the wages of Reds by the amount of the subsidy whatever the firm. The method of subsidy funding only changes the impact of the policy on the global welfare and the wages of Greens. In the case of borrowing and as our workers are not forward looking, the wages of Greens are unchanged and welfare increases. If the government has to balance receipts and expenses, subsidies are borne by all workers, so this is equivalent to a tax on the hiring of Green workers and the total welfare remains constant. In the case of a flat rate tax on employment, the total welfare does not change and the surplus of workers is equivalent to the loss of firms' welfare. Within workers, Greens lose a part of their surplus whereas Reds increase their welfare.

\subsection{Wage equalization}

With a policy of wage equalization, firms have to offer the same wage to all equally productive workers. This policy exists in most of countries. Wage equality between men and women doing equal work has been introduced in 1963 in the USA law and in the 1957 Treaty in order to fight gender discrimination among others. In spite of the introduction of legal principles, the difference between wages of women and men remains large $-16.4 \%$ in the $\mathrm{EU}$ on average for instance.

In our model, both groups of workers are equally productive. Firms then have to set the same wage for the Greens and the Reds. Their utility function becomes $U_{i}^{j}=$ $p\left(L_{G i}^{j}+L_{R i}^{j}\right)-w_{i}^{j} L_{G i}^{j}-\left(w_{i}^{j}+d_{i}\right) L_{R i}^{j}=p L_{i}^{j}-w_{i}^{j} L_{i}^{j}-d_{i} L_{R i}^{j}$. Utility maximization leads to the following reaction function:

$$
w_{i}^{j}=\frac{1}{2}\left(p-\frac{t}{4}+\bar{w}_{i}-\gamma d_{i}\right)
$$

Firms set a single wage, and the wage gap totally vanishes within each firm. The wage now depends on the proportion of Reds in the working population. The more there are, the lower is the firm's wage. The wage differential between unprejudiced and prejudiced firms is $\frac{1}{3} \gamma d$. Consequently, Reds earn higher wages than they would have without wage equalization as $\gamma<1$, but the wages of Greens are lower. Moreover, unprejudiced firms employ a greater number of both Red and Green workers than do prejudiced firms due to the higher wage. Nevertheless, the wages of Greens are lower than they would have been without the policy.

The global welfare slightly decreases due to this policy. The disappearance of the direct impact of discrimination on wages within firms negatively affects the well-being of the majority group and increases the wage of Reds. Consequently, in a democratic system 
Table 1 Impact of reforms in the case of a four-firm market-firms alternate

\begin{tabular}{|c|c|c|c|c|c|}
\hline & Policy & & Employment subsidies & Wage equalization & Minimum wage \\
\hline \multirow[t]{2}{*}{ Wages } & Reds & $\begin{array}{l}\text { Unprejudiced } \\
\text { Prejudiced }\end{array}$ & $w_{R i}^{k}=p+s-\beta-\frac{t}{4}-\frac{1}{3} d$ & $\begin{array}{l}w_{R i}^{u}=p-\frac{t}{4}-\frac{1}{3} \gamma d \\
w_{R i}^{p}=p-\frac{t}{4}-\frac{2}{3} \gamma d\end{array}$ & $w_{R i}^{k}=\underline{w}$ \\
\hline & Greens & $\begin{array}{l}\text { Unprejudiced } \\
\text { Prejudiced }\end{array}$ & $w_{R i}^{k}=p+s-\beta-\frac{t}{4}-\frac{2}{3} d$ & $\begin{array}{l}w_{G i}^{u}=p-\frac{t}{4}-\frac{1}{3} \gamma d \\
w_{G i}^{p}=p-\frac{t}{4}-\frac{2}{3} \gamma d\end{array}$ & $w_{G i}^{k}=p-\frac{t}{4}$ \\
\hline \multirow[t]{4}{*}{ Global welfare } & & & $p-\frac{t}{16}-\gamma d+\gamma \frac{5}{9} \frac{d^{2}}{t}+s \gamma-\beta$ & $p-\frac{t}{16}-\gamma d+\gamma \frac{5}{9} \frac{d^{2}}{t}$ & $p-\frac{t}{16}-\frac{1}{2} \gamma d$ \\
\hline & Policy & & Transport improvement & Transport subsidies & Affirmative action \\
\hline & Rodd & Unprejudiced & $w_{P}^{k}=p+s-\beta$. & $w_{\beta i}^{k}=p+s-\beta$ & $W_{R i}^{u}=p-\frac{t}{4}\left(1-(1-\tau) \frac{\tau(1-\gamma)-\gamma(1-\tau)}{k}\right)-\frac{1}{3} \frac{\tau^{2}(1-\gamma)}{k} d$ \\
\hline & heds & Prejudiced & & & $w_{R i}^{p}=p-\frac{t}{4}\left(1-2(1-\tau) \frac{\tau(1-\gamma)-\gamma(1-\tau)}{k}\right)-\frac{2}{3} \frac{\tau^{2}(1-\gamma)}{k} d$ \\
\hline \multirow{2}{*}{ Wages } & & Unprejudiced & & & $w_{G i}^{u}=p-\frac{t}{4}\left(1+\tau \frac{\tau(1-\gamma)-\gamma(1-\tau)}{k}\right)-\frac{1}{3} \tau \frac{\gamma(1-\tau)}{k} d$ \\
\hline & Greens & Prejudiced & $w_{G i}^{k}=p+s-\beta-\frac{t}{4}-\frac{1}{3} d$ & $w_{G i}^{k}=p+s-\beta-\frac{t}{4}-\frac{1}{3} d$ & $w_{G i}^{p}=p-\frac{t}{4}\left(1+2 \tau \frac{\tau(1-\gamma)-\gamma(1-\tau)}{k}\right)-\frac{2}{3} \tau \frac{\gamma(1-\tau)}{k} d$ \\
\hline Global welfare & & & $p-\frac{t^{\prime}}{16}-\gamma d+\gamma \frac{5}{9} \frac{d^{2}}{t^{\prime}}$ & $\begin{aligned} p- & \frac{t}{16}-\gamma d+\gamma \frac{5}{9} \frac{d^{2}}{t}-T \\
& +\gamma s\left(\frac{1}{4 n}+\frac{d^{2}}{36 t}\right)\end{aligned}$ & $\begin{array}{c}p-\frac{t}{16}-\gamma d+\gamma \frac{5}{9} \frac{d^{2}}{t}+\frac{1}{9 t}\left[\lambda\left(\lambda\left(-\gamma+2 \gamma \tau-\tau^{2}\right)\right.\right. \\
-4 d \gamma(1-\tau))]\end{array}$ \\
\hline
\end{tabular}


where economic agents maximize their revenues, the government will have no political incentive to reduce discrimination for fear of not being re-elected.

\subsection{Minimum wage}

Introduction of a minimum wage is a frequent policy to alleviate the poverty of working poor. Blumkin and Danziger (2014) show that this policy can be socially beneficial to supplement an optimal tax-and-transfer system. However, depending on the level of minimum wage, wage distribution is truncated for low productivity workers. In this case, it could have a negative impact on employment (Addison et al. (2015) for a recent study). Only few developed countries did not adopt the minimum wage. Germany introduces it in 2015, and Italy plans to do it.

In our study, this policy aims at increasing Red wages and consequently reducing wage gap. Three different cases can arise. The minimum wage is binding for all wages; it is binding for Red wages only; it is binding for Red wages of prejudiced firms. I study the last case as the results of the second case are more complicated and the comparison is not easy. Theoretically, the welfare should be between the benchmark case and the case when minimum wage is binding for all Red wages.

Green wages are not impacted by minimum wage. Only Red wages are binding by minimum wage and $w_{i R}^{j}=\underline{w}$. Minimum wage induces a decrease of the wage gap between Reds and Greens. Red treatment is identical whatever the type of the firm. The welfare increase in $\frac{1}{2} d-\gamma \frac{5}{9} \frac{d^{2}}{t}$ if $\gamma d \leq \frac{9}{10} t$. As shown in the literature, ${ }^{5}$ the existence of monopsony power raises the possibility that minimum wage increases employment.

\subsection{Affirmative action}

Affirmative action policies take different forms, ranging from requirements to give special consideration to those from minority groups to setting quotas on employment of minority workers. Affirmative action policy was introduced in the USA to promote blacks in education system and labor market. For instance in France, firms have to hire a quota of disable people or to pay a tax. Concerning women, targets and quotas for the promotion or recruitment of women in employment are rarer. Recently, some countries have adopted legislation aimed at a more balanced gender representation in company boards (Finland, France, Germany, Italy, etc.). In some countries like Germany, public institutions are under an obligation to adopt equality plans to increase women's representation.

In our model, affirmative action consists in imposing a quota of minority workers on firms. This secures a minimum level of employment for workers who are discriminated against in each firm. Suppose that the aim is to employ a minimal proportion of $\tau$ Red workers in each firm. Assume that $\tau \leq \gamma$ in order to obtain a solution and that $\tau$ is greater than the proportion of Red workers in the prejudiced firm setting the lowest wage. Firms maximize their utility as in Section 2 under the constraint that $L_{R i}^{j} \geq \tau L_{G i}^{j}$.

The presence of the quota of Red workers affects all wages in all firms. The introduction of affirmative action increases the demand for the labor of Red workers in prejudiced firms and relatively reduces the demand for Green workers. This impact depends on the quota and the proportion of Red workers on the circle: the closer these two percentage terms are, the tighter is the market for Red workers and the higher is the wage of Reds. The general impact of the affirmative action policy is also positive 
for the wages of workers who are discriminated against and negative for the wages of workers belonging to the majority. The effect on the wages of workers in prejudiced firms is twice as high as that in unprejudiced firms. As discriminatory firms now employ relatively more Reds (and fewer Greens) than beforehand, Red wages have to be higher (and Green wages lower) to attract the required number of workers to the firm.

The total welfare does not change if $\tau=\frac{3 t \gamma-d n \gamma}{3 t-d n \gamma}$ and increases if $\tau$ is lower. However, as the Greens are the majority of the working population, governments which want to be re-elected will have little incentive to introduce this policy.

\subsection{Improving transport}

Investments in transportation infrastructure or in improving the city transportation network lead to lower commuting costs for all workers in the city. For instance, the French government policy of "Grand Paris" aims to reduce the commuting costs of poor workers located in the Paris suburbs. The project will improve access to the economic centers of Paris and its suburbs. As women's elasticity of labor supply is lower than men's elasticity, this policy will also reduce wage gap between men and women.

In the model, this policy implies lower $t$. As $t$ falls and $\left|w_{h i}-w_{h i+1}\right| \leq \frac{t}{4}$, the wage gap is smaller in percentage terms but remains the same in absolute terms as there is no interaction between the transportation cost and the discriminatory term. Moreover, the global welfare increases further to the policy if the project is not funded by taxes. Otherwise, the total welfare only increases if investment return is positive.

A transport policy thus increases wages and leads to a relative fall in the wage gap between the majority and the minority. The firms' market power on workers decreases due to fall of transportation costs but the wage of workers increases. In the particular case of sufficiently low commuting costs, the effect on discrimination is not straightforward.

\subsection{Transport subsidies}

A second indirect policy consists in subsidizing commuting costs. This is used to help particular populations (e.g., young people, unemployed, older people) but rarely women. For instance in France, employment agencies reimburse to unemployed commuting costs to a firm. Transport companies-SNCF, RATP, etc.-offer young and old people special prices but also people benefiting from minimum livelihoods.

In order to reduce the wage gap and favor the minority, the government supports financially a part of Reds' transportation costs. In the model, it is equivalent to have two different commuting costs, depending on the worker's group. Maximizing the welfare under the state budget constraint leads to a subsidy of $s=2 \sqrt{5} d$. Consequently, reaction functions become:

$$
\begin{aligned}
w_{G i}^{j} & =\frac{1}{2}\left(p-\beta-\frac{t}{4}+\bar{w}_{G i}\right) \\
w_{R i}^{j} & =\frac{1}{2}\left(p-\beta-\frac{t-s}{4}+\bar{w}_{R i}-d_{i}\right)
\end{aligned}
$$

The wage gap decreases by $\frac{s}{4}$ due to subsidies. However, payroll is not impacted by this policy and prejudiced firms hire less Reds than Greens. Firms lose a part of their market 
power on Reds because their commuting costs decreases. The total welfare increases of $\left(\frac{3}{4}+\frac{d^{2}}{36}\right) \gamma s$ with the subvention.

To conclude this section, indirect policy aiming at increasing labor market competition via better transport increases wages, but the wage gap remains the same in value. On the contrary, a transport subsidy for workers discriminated against leads to an increase of global welfare and a decrease of the wage gap. An employment subsidy for Red workers' employment does not lead to a first-best solution and has no impact on the wages of Greens when funded by borrowing. Wage equalization and affirmative action are more efficient policies: however, governments of economic agents maximizing their revenues have little incentive to introduce them as they reduce majority well-being.

\section{Conclusions}

This paper has shown that a taste-based model of discrimination can match the stylized facts of the persistence of discrimination. The model is based on the heterogeneity of worker preferences, which yields non-negligible employer market power over their workers. This assumption induces a wage gap, which will not disappear in equilibrium, reinforcing findings of previous models. Unprejudiced firms make non-zero profits due to the existence of discriminatory firms in the market and are thus not prompted to drive out prejudiced firms as they represent a source of profit. Contrary to most models in the literature, including Black (1995), there is no segregation between groups, and both types of workers are hired by all firms. Last but not the least, the existence of only one prejudiced firm in the market leads to a wage gap between Reds and Greens without there being any differences in observable productive abilities. The wage of Reds is not unique in the labor market, and the dispersion depends on the concentration of unprejudiced firms. Moreover, firms' location matters as a firm close to similar firms makes more profits.

Greater competition on the market reduces the wage gap but does not suffice to make it disappear, except if commuting costs totally vanish. Complementary policy initiatives are required for this, but if economic agents maximize their revenues, governments have no incentive to introduce them for re-election reasons. Improving transport or subsidizing commuting costs are most efficient and increase wages whatever the workers' color.

Firms are assumed to be homogeneous in this model. A model with heterogeneous firms and productivity levels could also be analyzed. It is also natural to expect more productive firms to have higher sales, which require a larger labor force. Being more productive, these firms can afford to pay higher wages to attract the additional workers they need. The wages of Greens will then follow some kind of distribution and will not be identical whatever the firm. However, the main results would remain unchanged.

\section{Endnotes}

${ }^{1}$ For the USA, see Black and Strahan (2001), Hellerstein et al. (1999), and Ashenfelter and Hannan (1986); Heywood and Peoples (1994) examine the banking industry and Peoples and Saunders (1993) the trucking industry.

${ }^{2}$ See Hellerstein et al. (2002) concerning women and Peoples and Talley (2001) and Comanor (1973) concerning Blacks, for American results. 
${ }^{3}$ Black and Brainerd (2004) study the USA case and Berik et al. (2004) Taiwan and Korea. Liberalization reduces the wage gap, except in Taiwan, where the wage gap effect is positive in concentrated industries.

${ }^{4}$ For a literature review of theoretical models dealing with racial discrimination and their limits, see Lang and Lehmann (2012). Models of Black (1995), Bowlus and Eckstein (2002), Rosén (2003), and Lang et al. (2005) are particularly significant in this literature.

${ }^{5}$ See Ashenfelter et al. (2010) for instance.

\section{Appendices}

\section{Appendix 1: the unique Nash equilibrium}

The optimal wage setting rule for all firms can be rewritten as a function of matrices:

$$
w_{j}=A_{j}+B w_{j}
$$

where $j$ is the type of workers, the matrix $A_{j}$ is a diagonal matrix composed of elements $a_{i}=\frac{1}{2}\left(p-\frac{t}{n}-d_{i}\right)$ where $d_{i}=0$ in $w_{G}$ or if the firm is unprejudiced and $d_{i}=d$ in $w_{R}$ if the firm is prejudiced. When $\eta=1 / 2$ and prejudiced firms are uniformly distributed on the circle city, $B$ is the following matrix:

$$
B=\left(\begin{array}{cccccc}
0 & \frac{1}{4} & 0 & \ldots & 0 & \frac{1}{4} \\
\frac{1}{4} & 0 & \frac{1}{4} & \ldots & 0 & 0 \\
0 & \frac{1}{4} & 0 & \ddots & \vdots \\
\vdots & & \ddots & \ddots & \frac{1}{4} & 0 \\
0 & 0 & & \frac{1}{4} & 0 & \frac{1}{4} \\
\frac{1}{4} & 0 & \ldots & 0 & \frac{1}{4} & 0
\end{array}\right)
$$

If the matrix $S=(I-B)^{-1}$ exists, then $w^{*}=S A$. The existence of a unique Nash equilibrium is based on two conditions:

1. Equation (6) is a contraction mapping. In this case, the function converges on its fix point whatever the wage initial vector. Consequently, the Nash equilibrium exists and is unique in each case.

2. $S$ exists. This condition is the mathematical condition to the existence for a solution.

\section{Condition 1}

Proof. Given $x, x^{\prime} \in \mathbb{R}$, let $d\left(x, x^{\prime}\right)=\max _{i}\left|x_{i}-x_{i}^{\prime}\right|$. Let $w, w^{\prime}$ be two wage vectors, and let $f, f^{\prime}$ be the associated optimal wages given by (6). For any $i$, we have

$$
\begin{gathered}
\left|f_{i}-f_{i}^{\prime}\right|=\frac{1}{4}\left|\left(w_{i-1}-w_{i-1}^{\prime}\right)+\left(w_{i+1}-w_{i+1}^{\prime}\right)\right| \\
\leq \frac{1}{4}\left[2 d\left(w, w^{\prime}\right)\right]
\end{gathered}
$$

Since $d\left(f, f^{\prime}\right) \leq \frac{1}{2} d\left(w, w^{\prime}\right),(6)$ is a contracting mapping. It is straightforward that $f$ is increasing, i.e., if $x \geq x^{\prime}$, then $f(x) \geq f\left(x^{\prime}\right)$. 


\section{Condition 2}

Proof. Since $I-B$ is a circulant matrix, $S$ is also a circulant matrix. Circulant matrices can be defined by their first row. Let $s=\left(s_{0}, s_{1}, \ldots, s_{n-1}\right)$. Note that $S(I-B)=I$. So $s$ must solve:

$$
\begin{aligned}
s_{0}-\frac{1}{4} s_{1}-\frac{1}{4} s_{n-1} & =1 \\
-\frac{1}{4} s_{k}+s_{k}-\frac{1}{4} s_{k+1} & =0 \quad \text { for } k=0,1, \ldots, n-3 \\
-\frac{1}{4} s_{0}-\frac{1}{4} s_{n-2}+s_{n-1} & =0
\end{aligned}
$$

Notice that the second equation is a second-order linear difference equation. Then, its characteristic roots are

$$
\begin{aligned}
& \lambda_{1}=\frac{1}{2}-\sqrt{3} \\
& \lambda_{2}=\frac{1}{2}+\sqrt{3}
\end{aligned}
$$

Since $0<\lambda_{1}<1<\lambda_{2}$, the general solution to the second equation is

$$
s_{k}=C \lambda_{1}^{k}+D \lambda_{2}^{k}
$$

for arbitrary constants $C$ and $D$. Substituting in the two other equations leads to a system of two equations with two unknowns, $C$ and $D$. Solving yields

$$
\begin{aligned}
& C=\frac{1}{\left(1-\lambda_{1}^{n}\right) \sqrt{3 / 4}} \\
& D=\frac{1}{\left(\lambda_{2}^{n}-1\right) \sqrt{3 / 4}}
\end{aligned}
$$

which are both positive. Therefore, $s_{t}>0 \forall k=0, \ldots, n-1$.

Since $S$ is circulant and symmetric, we could observe $s_{k}=s_{n-k}$ for $k=1, \ldots, \frac{n}{2}$. Since $\lambda_{1}<1$ and $\lambda_{2}>1$ and $s_{k}$ is non-monotonic in $k$, it must first be declining and then be rising. However, since $S$ is symmetric, it must be the case that $s_{0}>s_{1}>\ldots>s_{\frac{n}{2}}$.

Two more conditions are necessary to have a well-behaved equilibrium in order to bound $a_{i}$ given parameters $n, d$, and $t$. First, the market have to be covered. Second, the wage setting rule, which satisfies the first-order condition for profit maximization, has to be globally optimal. Concerning wages of Green workers, equilibrium wages are identical in each firms. Concerning wages of Reds, both conditions have to be verified.

The first condition suggests that, in equilibrium, $\forall i, \bar{i}$, where $\bar{i}=i+1$ or $\bar{i}=i-1, \mid w_{j i}-$ $w_{j \bar{i}} \mid \leq \frac{t}{n}$. It means that all workers work for one of the nearest firms. The maximum value taken by this difference is when all prejudiced firms are side by side and unprejudiced ones too. It implies the bound:

$$
\begin{aligned}
\frac{1}{2}\left(p-\frac{t}{n}\right)-\frac{1}{2}\left(p-\frac{t}{n}-d\right) & \leq \frac{1}{s_{0}-s_{\frac{n}{2}}} \frac{t}{n} \\
\Leftrightarrow d & \leq \frac{1}{s_{0}-s_{\frac{n}{2}}} \frac{t}{n}
\end{aligned}
$$

The second condition is that the market has to be covered. A firm does not want to choose a wage so high as to capture its neighbors' markets if the net revenue product 
should be no greater than the wage which would be sufficient to capture the neighboring labor market. It means that $a_{i} \leq \bar{w}_{i}^{*}+\frac{t}{n}$. This inequality is satisfied whenever

$$
\left(1-\frac{s_{i}}{2}\right) a_{i} \leq \frac{1}{2} \sum_{j=0, j \neq i}^{n-1} s_{j} a_{j}+\frac{1}{2} \frac{t}{n}
$$

To summarize, the first condition allows to cover the market and have an equilibrium. The second condition gives a bound which is greater than $a_{i}$ when $i$ is prejudiced provided that $t$ is sufficiently large.

\section{Appendix 2: a particular case: the uncovered market}

Individuals only work if their net wage is positive. In the main part, the assumption of a zero reservation wage and a reasonable level of discrimination allow the market to be covered. However, if wage does not compensate commutation costs, which means $d<$ $\frac{2 t}{n_{F}}$, worker is unemployed. Consequently, circle labor market is no more covered and an unemployment pool separates each firm. Firms are also monopsonists and wages set up by their neighbors does not matter anymore. Firm $i$ offers following wages if both labor markets are uncovered:

$$
\begin{array}{r}
w_{G i}^{j}=\frac{1}{2} p \\
w_{R i}^{j}=\frac{1}{2}\left(p-d_{i}\right)
\end{array}
$$

where $d_{i}=d$ if $j=u$ and zero otherwise. If the labor market of Greens is covered, findings concerning Greens in the previous part are still valid. In this case, Reds are only discriminated against by prejudiced firms and the wage gap is $d / 2$ in prejudiced firm and inexistent in unprejudiced firms.

Then, the wage bill is

$$
\begin{aligned}
L_{G i}^{j} & =\frac{1}{2 t}(1-\gamma) p \\
L_{R i}^{j} & =\frac{1}{2 t} \gamma\left(p-d_{i}\right)
\end{aligned}
$$

and the profit equation is

$$
\Pi_{i}^{j}=\frac{1}{4 t} p^{2}-\frac{1}{4 t} \gamma d_{i}^{2}
$$

An uncovered market means that distance between two firms is slightly higher than half the sum of wage bill of each nearby firms. Consequently, $n_{F}=\frac{t n_{w}}{p n_{w}+t}$ firms enter the market if both markets are uncovered. Moreover, between both types firms, $\frac{\gamma d^{2}}{2 t}+\frac{1}{n_{w}}$ Reds are unemployed whereas only $\frac{1}{n_{w}}$ Greens are unemployed between two firms.

\section{Appendix 3: a particular case: a small commuting cost}

If the transportation cost is sufficiently small that the wage differential between prejudiced and unprejudiced firms is greater than $\frac{t}{n_{F}}$, some workers will have an incentive to work for firms other than the two nearest. As such, other firms on the circle offer a net wage which is higher than that offered by the two nearest firms. Labor supply now depends on the type of firm that the worker can reach. If different types of firms alternate, no Red workers will choose to work for a prejudiced firm, as the wage proposed by unprejudiced firms is sufficiently high to compensate for the additional transporta- 
tion costs required to reach them. The labor supply of Reds is thus only shared between unprejudiced firms. Then, the labor supply of firm $i$ is

$$
\begin{array}{r}
L_{i}^{u}=\frac{1}{t}(1-\gamma)\left[\frac{t}{n_{F}}+\left(w_{G i}-\bar{w}_{G i}\right)\right]+\gamma \frac{1}{t}\left[\frac{2 t}{n_{F}}+w_{R i}-\bar{w}_{R i^{\prime}}\right] \\
L_{i}^{p}=\frac{1}{t}(1-\gamma)\left[\frac{t}{n_{F}}+w_{G i}-\bar{w}_{G i}\right]
\end{array}
$$

where $w_{R i^{\prime}}$ is the Red wage offered by the other unprejudiced firms.

Employers maximize their utility taking into account the labor supply and wages of their neighbors. Substituting labor supplies into utilities and then solving the first-order condition yields the following reaction function:

$$
\begin{aligned}
& w_{G i}=\frac{1}{2}\left(p-\frac{t}{n_{F}}+\bar{w}_{G i}\right) \\
& w_{R i}^{u}=\frac{1}{2}\left(p-\frac{2 t}{n_{F}}+\bar{w}_{R i^{\prime}}\right)
\end{aligned}
$$

Then equilibrium wages are

$$
\begin{aligned}
& w_{G i}=p-\frac{t}{n_{F}} \\
& w_{R i}^{u}=p-\frac{2 t}{n_{F}}
\end{aligned}
$$

The impact of the discrimination term $(d)$ is not directly observable because only unprejudiced firms are interested in hiring Red workers. This term intervenes only in the decision process of workers and no longer in the maximization process of firms. The labor demand for Red workers is also lower than that of Green workers. Due to this lower demand, the wage of Reds offered by unprejudiced firms is lower than that of Greens. The sub-market of Red workers contains only the unprejudiced firms. The market power of unprejudiced firms is thus greater than before and they set lower wages to maximize profits. Both unprejudiced firms are in competition a la Cournot. As in matching models, segregation can result because prejudiced firms do not hire Red workers and the wage differential comes essentially from the difference in labor demand between Reds and Greens. For the special case when $t=0$, workers can choose any firm without additional costs. Red workers choose one of the non-discriminatory firms and their wage stays lower because the demand for Reds' labor is lower than that for Greens and the labor market is segregated between unprejudiced and prejudiced firms. The wage gap is only based on the difference in the number of unprejudiced and prejudiced firms. The more unprejudiced firms there are on the market, the greater is the wage gap between both types of workers.

The situation is more complex as the firms are not symmetrically distributed on the market. The wage differential can then be sufficiently high between some firms that Red workers work for unprejudiced firms (but not between others). Consequently, some Red individuals will work for prejudiced firms because it is too expensive to reach the nearest unprejudiced firm. The market then becomes very heterogeneous and many situations can be conceived. The effect on the wage gap is ambiguous: the demand for Red labor is lower, and so is their wage. However, market power is no longer symmetrically shared and the fact that some firms have more market power reduces wages in some parts of the market and increases them in others. 


\section{Appendix 4: wage bills and profits}

\section{Appendix 4.1: wage bills}

When prejudiced and unprejudiced firms alternate $(A)$, the wage bills of the firms are

$$
\begin{aligned}
L_{R i}^{u} & =\frac{\gamma}{t}\left[\frac{t}{n_{F}}+\frac{1}{3} d\right] \\
L_{R i}^{p} & =\frac{\gamma}{t}\left[\frac{t}{n_{F}}-\frac{1}{3} d\right]
\end{aligned}
$$

When identical firms are side by side $(B)$, the wage bills of firms are

$$
\begin{aligned}
L_{R i}^{u} & =\frac{\gamma}{t}\left[\frac{t}{n_{F}}+\frac{1}{4} d\right] \\
L_{R i}^{p} & =\frac{\gamma}{t}\left[\frac{t}{n_{F}}-\frac{1}{4} d\right]
\end{aligned}
$$

\section{Appendix 4.2: profits}

When prejudiced and unprejudiced firms alternate $(A)$, the profits of firms are

$$
\begin{array}{r}
\Pi_{i}^{u}=\frac{(1-\gamma) t}{n_{F}^{2}}+\gamma \frac{1}{t}\left(\frac{t}{n_{F}}+\frac{d}{3}\right)^{2} \\
\Pi_{i}^{p}=\frac{(1-\gamma) t}{n_{F}^{2}}+\gamma \frac{1}{t}\left(\frac{t}{n_{F}}-\frac{d}{3}\right)\left(\frac{t}{n_{F}}+\frac{2 d}{3}\right)
\end{array}
$$

When identical firms are side by side $(B)$, the profits of the firms are

$$
\begin{array}{r}
\Pi_{i}^{u}=\frac{(1-\gamma) t}{n_{F}^{2}}+\gamma \frac{1}{t}\left(\frac{t}{n_{F}} \frac{d}{4}\right)^{2} \\
\Pi_{i}^{p}=\frac{(1-\gamma) t}{n_{F}^{2}}+\gamma \frac{1}{t}\left(\frac{t}{n_{F}}-\frac{3 d}{4}\right)\left(\frac{t}{n_{F}}-\frac{d}{4}\right)
\end{array}
$$

\section{Appendix 5: welfare derivatives}

$$
\begin{aligned}
& \frac{\partial W}{\partial p}=1 \\
& \frac{\partial W}{\partial t}=-\frac{1}{16}-\gamma \frac{5}{18} \frac{d^{2}}{t} \\
& \frac{\partial W}{\partial d}=\gamma\left(\frac{10}{9} \frac{d^{2}}{t}-1\right) \\
& \frac{\partial W}{\partial \gamma}=d\left(\frac{5}{9} \frac{d}{t}-1\right)
\end{aligned}
$$

\section{Competing interests}

The IZA Journal of Labor Economics is committed to the IZA Guiding Principles of Research Integrity. The author declares that she has observed these principles.

\section{Acknowledgements}

I am grateful to Yves Zenou, Pierre Cahuc and seminar participants at the Paris School of Economics, the AFSE Conference, and the Mainz Workshop in Labor Economics for their useful remarks. I thank the editor and reviewers for their comments and suggestions, which significantly contributed to improve the quality of the paper. This paper reflects the opinions of the author and does not necessarily express the views of the Banque de France.

Responsible editor: Joni Hersch

Received: 20 October 2015 Accepted: 8 April 2016

Published online: 29 April 2016

\section{References}

Addison J, Blackburn M, Cotti C (2015) On the robustness of minimum wage effects: geographically-disparate trends and job growth equations. IZA J Labor Econ 4(1):1-16 
Altonji JG, Pierret CR (2001) Employer learning and statistical discrimination. Q J Econ 116(1):313-350. NBER Working Papers 6279

Arrow KJ (1971) The theory of discrimination. Princeton University, Department of Economics, Industrial Relations Section 403

Ashenfelter O, Hannan T (1986) Sex discrimination and product market competition: the case of the banking industry. Q J Econ 101(1):149-73

Ashenfelter O, Farber H, Ransom M (2010) Labor market monopsony. J Labor Econ 28(2):203-210

Barth C, Dale-Olsen H (2009) Monopsonistic discrimination, worker turnover and the gender wage gap. Labour Econ 16(5):589-597

Becker $G$ (1971) The economics of discrimination. University of Chicago Press

Berik G, van der Meulen Rodgers Y, Zveglich JJ (2004) International trade and gender wage discrimination: evidence from east asia. Rev Dev Econ 8(2):237-254

Bhaskar V, To T (2003) Oligopsony and the distribution of wages. Eur Econ Rev 47(2):371-399

Bhaskar V, Manning A, To T (2002) Oligopsony and monopsonistic competition in labor markets. J Econ Perspect 16(2):155-174

Black DA (1995) Discrimination in an equilibrium search model. J Labor Econ 13(2):309-33

Black S, Brainerd E (2004) Importing equality? The impact of globalization on gender discrimination. Ind Labor Relat Rev 57(4):540-559

Black S, Strahan P (2001) The division of spoils: rent-sharing and discrimination in a regulated industry. Am Econ Rev 91(4):814-831

Blumkin T, Danziger L (2014) Deserving poor and the desirability of a minimum wage, IZA Discussion Paper No. 8418 https://ideas.repec.org/p/iza/izadps/dp8418.html

Boal W, Ransom M (1997) Monopsony in the labor market. J Econ Lit 35(1):86-112

Bonhomme S, Jolivet G (2009) The pervasive absence of compensating differentials. J Appl Economet 24:763-795

Booth AL, Katic P (2011) Estimating the wage elasticity of labour supply to a firm: what evidence is there for monopsony? Econ Record 87(278):359-369

Bowlus A, Eckstein Z (2002) Discrimination and skill differences in an equilibrium search model. Int Econ Rev 43(4):1309-1345

Brueckner JK, Thisse JF, Zenou Y (2002) Local labor markets, job matching, and urban location. Int Econ Rev 43(1):151-171

Comanor W (1973) Racial discrimination in american industry. Economica 40(160):363-378

Falch T (2011) Teacher mobility responses to wage changes: evidence from a quasi-natural experiment. Am Econ Rev 101(3):460-65

Hamilton J, Thisse JF, Zenou Y (2000) Wage competition with heterogeneous workers and firms. J Labor Econ 18(3):453-472

Hellerstein J, Neumark D, Troske K (1999) Wages, productivity, and worker characteristics: evidence from plant-level production functions and wage equations. J Labor Econ 17(3):409-446

Hellerstein J, Neumark D, Troske K (2002) Market forces and sex discrimination. J Hum Resour 37:353-380

Heywood J, Peoples J (1994) Deregulation and the prevalence of black truck drivers. J Law Econ 37(1):133-155

Hotelling H (1929) Stability in competition. Econ J 39(153):41-57

Lang K, Lehmann JYK (2012) Racial discrimination in the labor market: theory and empirics. J Econ Lit 50(4):959-1006

Lang K, Manove M, Dickens W (2005) Racial discrimination in labor markets with posted wage offers. Am Econ Rev 95(4):1327-1340

Lemoine M, Wasmer E (2010) Collection: Les Rapports du Conseil d'analyse économique. Editor: La Documentation française

Manning A (2003a) Monopsony in motion: imperfect competition in labour markets. Princeton University Press Manning A (2003b) The real thin theory: monopsony in modern labour markets. Labour Econ 10:105-131

Manning A (2010) The plant size-place effect: agglomeration and monopsony in labour markets. J Econ Geography 10(5):717-744

Manning A (2011) Imperfect competition in the labor market, vol 4B. David Card and Orley Ashenfelter, chap 11

Manning A, Petrongolo B (2011) How local are labor markets? Evidence from a spatial job search model. https://ideas. repec.org/p/cpr/ceprdp/8686.html

Peoples JJ, Saunders L (1993) Trucking deregulation and the black/white wage gap. Ind Labor Relat Rev 47:23-35

Peoples JJ, Talley W (2001) Black-white earnings differentials: privatization versus deregulation. Am Econ Rev 91(2):164-168

Phelps E (1972) The statistical theory of racism and sexism. Am Econ Rev 62(4):639-651

Ransom M, Oaxaca R (2010) New market power models and sex differences in pay. J Labor Econ 28(2):267-289

Ransom MR, Sims DP (2010) Estimating the firm's labor supply curve in a "new monopsony" framework: school teachers in Missouri. J Labor Econ 28(2):331-355

Robinson J (1934) The economics of imperfect competition. Journal of the Royal Statistical Society 97(4):671-674

Rosén A (2003) Search, bargaining and employer discrimination. J Labor Econ 21:807-829

Rupert P, Wasmer E (2007) Housing and the labor market: time to move and aggregate unemployment. J Monetary Econ 59(1):24-36

Salop SC (1979) Monopolistic competition with outside goods. Bell J Econ 10(1):141-156

Staiger D, Spetz J, Phibbs C (2010) Is there monopsony in the labor market? Evidence from a natural experiment. J Labor Econ 28(2):211-236

Thisse JF, Zenou Y (1995) Appariement et concurrence spatiale sur le marché du travail. Revue Economique 46(3):615-625

Wasmer E (2006) Interpreting Europe-US labor market differences: the specificity of human capital investments. Am Econ Rev 93(3):811-831

Wauthy X, Zenou Y (1999) Le rôle de l'hétérogénéité des agents sur le marché du travail en concurrence imparfaite. Revue Economique 50(5):965-984 